\title{
Voluntariado de Adolescentes na Humanização Hospitalar: uma Via de Mão Dupla
}

\author{
Camargo, Mariana Cristina; Luzo, Maria Candida de Miranda \\ Instituto de Ortopedia do Hospital das Clínicas da Faculdade de Medicina da Universidade de São \\ Paulo _ maricamargo.to@gmail.com
}

Introdução o processo de hospitalização ou dedicação a um tratamento gera uma ruptura na rotina da criança afetando diretamente o seu desenvolvimento. a vivência da rotina hospitalar, que prioriza o diagnóstico e quadro clínico, pode ser uma experiência traumatizante, uma vez que a pessoa deixa de ter autonomia sobre sua vida e permanece desprovida de desejos. Sendo assim, dar à pessoa a oportunidade de ter desejos e fazer escolhas em alguns momentos pode tornar o ambiente hostil do hospital em uma experiência positiva. Objetivos a partir da análise deste problema detectou-se a oportunidade de realização de uma parceria entre o hospital e um colégio particular de São Paulo, possibilitando a participação da comunidade nos projetos sociais e atividades de humanização desenvolvidas dentro do hospital e promovendo ações para que os alunos tenham a oportunidade de compreender melhor o exercício da cidadania, a responsabilidade social e ambiental. a proximidade entre o colégio e o hospital favoreceu essa parceria, visto que as duas Instituições possuem diretrizes que possibilitam essa interação. Métodos a prática iniciou-se pela sensibilização dos alunos participantes e também de seus pais para que conhecessem as rotinas, os ambientes e os conceitos básicos e simples de saúde, doença e internação hospitalar. uma vez iniciadas as visitas os alunos desenvolvem atividades lúdicas semanalmente com os pacientes nos leitos, na brinquedoteca e na sala de espera pelas consultas ambulatoriais, acompanhados por professores do colégio e supervisionados pela equipe de profissionais qualificados, que dá suporte técnico e orienta a atuação dos voluntários. As atividades envolvem visitas aos pacientes acamados, oficinas de atividades das quais os alunos tenham habilidades, campanhas de arrecadação de brinquedos e materiais e organização de eventos comemorativos. em contrapartida a equipe do hospital promove palestras educativas e ações de saúde no colégio. Resultados Após sete anos de desenvolvimento do voluntariado é possível observar e colher relatos dos pacientes, acompanhantes e equipe de saúde de que os pacientes se mostram mais alegres, motivados e receptivos aos procedimentos, demonstrando ansiedade na espera pela visita dos alunos e estes, por sua vez referem satisfação ao desenvolver as atividades criando expectativas para o próximo encontro. Conclusões: a interação favoreceu a identificação, tanto dos pacientes, pela oportunidade de estar com pessoas da sua faixa etária ou próxima, com os mesmos interesses, questionamentos, vocabulário, etc., quanto para os alunos que criam empatia com os pacientes ao entrar em contato com alguém do seu universo que vivencia uma situação difícil e dolorosa.

Camargo, Mariana Cristina; Luzo, Maria Candida de Miranda. Voluntariado de Adolescentes na Humanização Hospitalar: uma Via de Mão Dupla. In: Anais do Congresso Internacional de Humanidades \&

Humanização em Saúde [= Blucher Medical Proceedings, num.2, vol.1]. São Paulo: Editora Blucher, 2014. ISSN 2357-7282

DOI 10.5151/medpro-cihhs-10586 